\title{
Klinische probleemanalyse als methodiek in het onderwijs in probleemoplossingsvaardigheden in het Nijmeegse geneeskundecurriculum
}

\author{
J.C.G. Jacobs, B.M. Cools, C.T. Postma
}

\section{Samenvatting}

Inleiding: In het U.M.C. St. Radboud te Nijmegen wordt sinds de start van de curriculumvernieuwing in 1995 aan de studenten een methode aangeboden om klinische problemen systematisch te analyseren, de Klinische Probleemanalyse. Tijdens alle blokken van het kerncurriculum worden anatomische en pathofysiologische inzichten gekoppeld aan bijbehorende ziektegeschiedenissen.

Beschrijving: Erwordt kort ingegaan op de methoden om medisch probleemoplossen te leren. Vervolgens wordt de huidige aanpak in Nijmegen, conform de Klinische Probleemanalyse, beschreven. Met name wordt het kleinschalig onderwijs in de blokken Praktisch Klinisch Onderwijs in het derde en vierde studiejaar beschreven. Hierin wordt casuïstiek uit de interne geneeskunde zodanig aangeboden dat de realiteit dicht benaderd wordt. Hiertoe wordt gebruik gemaakt van 'levensechte' patiëntengeschiedenissen, modelstatussen met aanvullende gegevens en video-opnamen van anamnesegesprekken. Tijdens de klinische co-assistentschappen blijven studenten de Klinische Probleemanalyse hanteren, evenals tijdens de centrale co-assistentschappen. Zowel studenten als docenten waarderen deze vernieuwing in het onderwijs om kennis te leren organiseren, integreren en toe te passen als zeer positief.

Beschouwing: De Klinische Probleemanalyse biedt tijdens het hele curriculum een gestructureerde aanpak van medisch probleemoplossen waarbij de casuïstiek de werkelijkheid steeds meer benadert. Studenten worden gestimuleerd hun kennis te activeren en actief deel te nemen aan het leerproces. Vergelijkend onderzoek naar de resultaten van het onderwijs in medisch probleemoplossen aan de verschillende medische faculteiten wordt aanbevolen. (Jacobs JCG, Cools BM, Postma CT. Klinische probleemanalyse als methodiek in het onderwijs in probleemoplossingsvaardigheden in het Nijmeegse geneeskundecurriculum. Tijdschrift voor Medisch Onderwijs 2002;21(2):64-74.)

\section{Inleiding}

Een belangrijk aspect in de opleiding geneeskunde is het leren hanteren van klinische informatie. Dit betreft in eerste instantie met name de gegevens die worden verkregen via de anamnese en het lichamelijk onderzoek. Deze bevindingen, die ook wel de klachten en symptomen worden genoemd, zijn de basis voor het verdere beleid, dat vervolgens weer nieuwe gegevens kan opleveren.

Het geneeskundecurriculum in Nijmegen is erop gericht de studenten vanaf vroeg in de studie vertrouwd te maken met het selecteren en analyseren van gegevens uit anamnese en lichamelijk onderzoek en deze te koppelen aan ziekten en aandoeningen. Hiermee wordt bereikt dat de studenten de verbinding leren zien tussen klachten en symptomen en de onderliggende pathofysiologie. Bij vrijwel al het theoretisch onderwijs in het kerncurriculum wordt via patiëntencasuïstiek het verband gelegd met klinische problematiek. Hierdoor, zo is althans de verwachting, zal het geleerde beter beklijven en tijdens de klinische stages in de juiste context weer sneller paraat zijn. Tijdens de blokken die 
gericht zijn op het trainen van specifieke vaardigheden voor het zelfstandig uitvoeren van patiëntencontacten wordt ook de vaardigheid in het omgaan met patiëntengegevens en het oplossen van klinische problemen verder ontwikkeld.

Algemeen wordt aangenomen dat probleemoplossingsvaardigheden verbonden zijn met kennis van een bepaald vakgebied. ${ }^{1}$ Aangezien medisch studenten in de eerste vier jaren van hun studie en aan het begin van de co-assistentschappen nog niet zo veel (ervarings)kennis hebben, kan men zich afvragen of het wel zinvol is de studenten in een vroege fase van de opleiding probleemoplossingsvaardigheden aan te leren. Een van de argumenten om dit toch te doen is dat relevante kennis zich het beste kan ontwikkelen tijdens het oplossen van klinische vraagstukken. ${ }^{2}$ Een voorwaarde hierbij is wel dat de studenten in staat zijn ziektegeschiedenissen zinvol te bestuderen. Om dit mogelijk te maken is in het Nijmeegse curriculum geneeskunde de Klinische Probleemanalyse geïntroduceerd. Met deze methode kunnen studenten ingewikkelde ziektegeschiedenissen aanpakken ook als ze nog niet beschikken over uitgebreide kennis. Terwijl studenten via toegepaste casuïstiek relevante kennis verwerven, worden zij tegelijkertijd getraind in het oplossen van klinische problemen. Met de Klinische Probleemanalyse leren zij een methode en strategie toepassen waarmee klinische problemen kunnen worden aangepakt door adequaat en logisch te redeneren met directe relaties naar de pathofysiologie. Het stramien van de Klinische Probleemanalyse wordt in het hele curriculum toegepast.

Een van de veronderstellingen is dat de methode van de Klinische Probleemanalyse studenten beter zal toerusten voor de klinische fase, doordat ze al vroeg in het curriculum een methode leren om gestructureerd en weloverwogen ziektegevallen te analyseren. De verwachting is dat hierdoor de overgang van het theoretisch onderwijs naar de klinische fase (soms 'shock of practice' genoemd) soepeler zal verlopen.

In dit artikel wordt eerst kort ingegaan op verschillende benaderingen en uitgangspunten voor onderwijs in klinisch probleemoplossen. Vervolgens worden de Klinische Probleemanalyse en de toepassing hiervan in het nieuwe Nijmeegse curriculum besproken.

\section{Onderwijsbenaderingen voor klinisch probleemoplossen}

De manieren waarop probleemoplossingsvaardigheden aangeleerd worden zijn divers. ${ }^{3-10}$ Klassiek is de docentgecentreerde aanpak waarbij de docent hardop denkt en als rolmodel fungeert. ${ }^{11}$ Door een veelheid aan klachtenpresentaties te bespreken, waarbij vaak de patiënt zelf aanwezig is, leert de student van de genomen denkstappen. Dit proces kan in grote of kleine groepen plaatsvinden en de mate van interactie tussen docent en groep en tussen de studenten onderling kan verschillen. Zo werden in het voorgaande Nijmeegse curriculum probleemoplossingsvaardigheden onderwezen in interactieve colleges. Docenten presenteerden patiënten en de studenten formuleerden de vragen van de anamnese en de differentiaaldiagnostische overwegingen. Naast begeleiding door docenten/tutoren werd elders er ook gewerkt met student-begeleiders van kleine groepen. Onderwijs in klinisch redeneren kan gebonden zijn aan een bepaald blok of longitudinaal geprogrammeerd zijn naast het overige onderwijs, zoals bij het klinisch lijnonderwijs. Inhoudelijk kan het klinisch lijnonderwijs al of niet gekoppeld zijn aan de onderwerpen waar studenten op dat moment mee bezig zijn. De presentatie van de proble- 
men varieert in complexiteit en realiteitsgehalte, van ziektegeschiedenissen op papier tot video-opnamen en contacten met echte patiënten.

Bij de docentgecentreerde aanpak kan de gebruikte systematiek per docent verschillen. Het is vaak moeilijk de impliciete ervaringskennis - de klinische blik - te verwoorden en over te dragen. Een nadeel van grootschalig onderwijs in klinisch redeneren is het risico van passief 'meeliften' van een deel van de studenten. Bij het disciplineoverstijgend en in meerdere studiejaren aanbieden van dit onderwijs (zoals de varianten van klinisch lijnonderwijs) wordt soms een gebrek aan relevante parate kennis bij de studenten ervaren. Kenmerkend voor de Nijmeegse Klinische Probleemanalyse is dat er vanaf het begin van het curriculum gewerkt wordt met dezelfde systematische methode om de klachten en symptomen van de patiënt te analyseren, die zowel geschikt is voor beginners als voor experts. ${ }^{12}$

\section{Welke elementen zou een goede methode moeten bevatten?}

Het is wenselijk dat een afnemende sturing door docenten gekoppeld wordt aan toenemende zelfsturing door studenten. Een docent zou hierbij vooral moeten fungeren als facilitator van het onderwijsleerproces. ${ }^{11} 13$ Onderwijs waarbij docenten eenzijdig het proces bepalen mist de toegevoegde waarde van het leren van 'peers', medestudenten met een gelijk ontwikkelingsniveau van kennis en vaardigheden. Vaak hebben studenten sneller inzicht in elkaars denkstappen en -fouten dan docenten. ${ }^{14}$ Daarnaast moet leren in de context zich niet te lang beperken tot 'papieren' casuïstiek. ${ }^{15}$ Hoe verder een werkwijze verwijderd is van de realiteit, hoe geringer het leereffect. Het is belangrijk dat er veel verschillende contexten aangeboden worden om de transfer van het geleerde te bevorderen. Om de motivatie te verhogen en vast te houden is het belangrijk dat een onderwijsmethode voor de studenten aantrekkelijke en uitdagende elementen bevat.

Inhoudelijk is het belangrijk dat een methodiek in zoveel mogelijk situaties toepasbaar en specialisme-overstijgend is. Het is aan te bevelen dat docenten en begeleiders tijdens de eerste studiejaren gebruik maken en verwijzen naar dezelfde methodiek om medische problemen op te lossen. Een effectieve implementatie vereist dat de aanpak bekend is bij en onderschreven wordt door de betrokken docenten, ook die van de klinische stages.

\section{Klinische Probleemanalyse}

\section{De procedure}

Van de Klinische Probleemanalyse zoals in Nijmegen toegepast zijn reeds eerder de theoretische achtergronden en uitwerking beschreven. ${ }^{12} 16$ Benadrukt moet worden dat de Klinische Probleemanalyse een systematische aanpak van medisch probleemoplossen biedt voor studenten vanaf het eerste studiejaar ('novices'). Het bevordert in sterke mate het 'forward' redeneren (van data naar diagnose) zoals experts dat blijken te vertonen, tegenover het 'backward' redeneren (van diagnose naar klacht) waartoe beginnende studenten neigen. ${ }^{17}$

Onder leiding van de docent worden in het Nijmeegse model via een cyclisch proces de problemen uit een ziektegeschiedenis geïdentificeerd en geanalyseerd. Uit de gegevens van de anamnese en het lichamelijk onderzoek selecteren de studenten de afwijkende gegevens en bijzondere kenmerken van de patiënt. Dit worden de activerende gegevens genoemd. Hierna wordt een probleemlijst samengesteld waarbij de activerende gegevens voorzover mogelijk gegroepeerd en vervolgens benoemd worden als problemen. 
Figuur 1. Schematische weergave Klinische Probleemanalyse

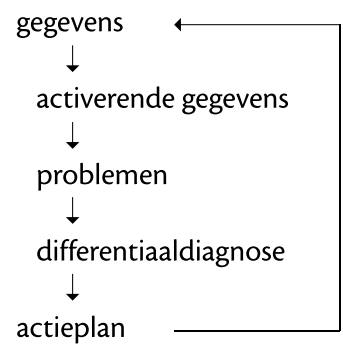

Per probleem wordt een analyse gemaakt naar oorzaak en gevolg. Hierbij kan bijvoorbeeld een (patho)fysiologische of anatomische ordening gekozen worden als basis voor de analyse. Hierna wordt een differentiaaldiagnose geformuleerd waarbij op basis van de analyse wordt beredeneerd wat voor de betreffende patiënt de meest waarschijnlijke oorzaak van de verschijnselen is. Dit wordt gevolgd door een actieplan: een diagnostisch en therapeutisch beleidsplan, gebaseerd en gericht op de analyse per probleem van de probleemlijst. Na de uitvoering van een gericht diagnostisch actieplan komt nieuwe informatie beschikbaar en wordt bekeken welke wijzigingen dit met zich meebrengt voor de probleemlijst, de differentiaaldiagnose en het actieplan. Het geheel vormt aldus een cyclisch proces (figuur 1).

Hieronder volgt ter verduidelijking een voorbeeld van de analyse van een casus volgens de Klinische Probleemanalyse. Eerst worden de gegevens van de patiënt gepresenteerd en vervolgens de daaruit afgeleide lijst met activerende gegevens, de probleemlijst en de analyse van problemen uit de lijst (figuur 2).

Aangenomen wordt dat op bovengeschetste wijze reeds aanwezige kennis wordt geactiveerd, denkstappen geëxpliciteerd en strategieën ontwikkeld om klinische problemen op te lossen. Een andere veronderstelling is dat studenten die vanaf het begin van hun studie leren om medische problemen systematisch te analyseren, ook later in de praktijk gebruik zullen maken van systematische probleemoplossingstrategieën. Tevens zou de organisatie van hun kennis verbeteren. De werkwijze van de Klinische Probleemanalyse stimuleert studenten om kennis gericht toe te passen en aanvullende kennis te verwerven. Anatomische en pathofysiologische inzichten worden zo geïntegreerd met ziektegeschiedenissen.

\section{De plaats in het curriculum}

De Klinische Probleemanalyse wordt in het eerste studiejaar geïntroduceerd. In de eerste vier studiejaren wordt gewerkt met eenvoudige, papieren casuïstiek die past binnen de problematiek van het betreffende blok. In de meeste blokken van het kerncurriculum wordt op deze wijze aandacht besteed aan klinische vraagstukken en de systematische aanpak daarvan. Geleidelijk aan neemt de complexiteit van de gepresenteerde casus toe. In de blokken Praktisch Klinisch Onderwijs in het derde en vierde studiejaar (PKO-1 en PKO-2) ligt het accent op de voorbereiding op de klinische stages. Hieronder wordt de implementatie van de Klinische Probleemanalyse in deze blokken gedetailleerd beschreven. Tijdens de co-assistentschappen worden de patiëntenpresentaties door de co-assistenten gestructureerd volgens de methode van de Klinische Probleemanalyse, evenals de verslaglegging en het uitwerken van de casuïstiek. De co-assistentenbegeleiders besteden hier specifiek aandacht aan. Ook tijdens de centrale co-assistentschappen - periodes van vier weken tussen de klinische co-assistentschappen - worden de patiëntenpresentaties gestructureerd volgens de systematiek van de Klinische Probleemanalyse. 
Figuur 2. Analyse van een casus volgens de Klinische Probleemanalyse.

\begin{abstract}
Speciële anamnese
In aansluiting aan een week waarin een patiënte van 54 jaar verschijnselen had gehad die zij en haar huisarts hadden geduid als griep werd patiënte sinds een week voor opname toenemend moe. Het ging haar steeds slechter. Ze werd regelmatig benauwd terwijl ze dat daarvoor nooit was geweest. Zij had koorts die opliep tot 39 graden. Zij had aanvankelijk ook pijn links op de thorax gehad die erger werd bij ademen maar dat was na twee dagen duidelijk afgenomen. Verder was zij ook gaan hoesten waarbij zij geel/groenig sputum opgaf. Zij had als huisdier een poes maar geen vogels of andere dieren. Zij was niet in het buitenland geweest in het afgelopen jaar noch in een hotel of andere omgeving waar veel mensen bijeen waren. Zij woonde met haar echtgenoot die een baan heeft in de IT, zijzelf was lerares op een middelbare school. Zij rookte niet en had ook nooit gerookt. Astma had zij nooit gehad evenmin had zij in het verleden klachten van de longen. Als sport beoefende zij tennis, soms twee keer per week, totdat ze de periode met "griep" kreeg. Voorheen had zij nooit beperkingen gehad in haar lichamelijke activiteiten.
\end{abstract}

\section{Tractusanamnese}

Algemeen:

Tr. Circulatorius:

Tr. Respiratorius:

Tr. Digestivus:

Tr. Urogenitalis:

Centr. Zenuwst.:

Endocrien:

Tr. Locomotorius:

Allergieën:

Intoxicaties:

Medicatie bij opname:

Familie:

Voorgeschiedenis:

\section{Lichamelijk Onderzoek}

Algemene indruk:

Hoofd/Hals:

Thorax:

Abdomen:
Slaapt matig-slecht (vanwege benauwdheid en het hoesten), koorts + , gewicht is $3 \mathrm{~kg}$ afgenomen, nu $77 \mathrm{~kg}$, snel moe, nachtzweten +.

Oedeem: ze heeft al jaren last van dikke enkels, toenemend in de loop van de dag, verder geen klachten.

Zie ook speciële anamnese, piepen-, TBC-, pneumonie-.

Geen bijzonderheden.

Lichte incontinentieklachten bij hoesten, verder geen bijzonderheden. Drie keer zwanger geweest, drie gezonde kinderen.

Visus: goed met leesbril.

Geen bijzonderheden.

Rug: af en toe wat pijnklachten onder in de rug, maar niet zo ernstig dat ze hiervoor behandeling behoeft, na rust herstelt dit snel.

Geen bekend.

Roken -, alcohol 3 eenh./week; drugs -

Sinds twee dagen doxycycline 1 maal daags $100 \mathrm{mg}$.

Geen relevante aandoeningen.

Niet bekend met ziekten of aandoeningen, geen operatieve ingrepen.

Vitale 54-jarige vrouw, biologische leeftijd conform kalenderleeftijd, met last van benauwdheid, hoest regelmatig. lets pitting oedeem boven de enkels. Geen anemie, geen cyanose of icterus. Lengte $1.77 \mathrm{~m}$, gewicht $76 \mathrm{~kg}$. RR $117 / 76 \mathrm{mmHg}$ rechts, $110 / 70 \mathrm{mmHg}$ links (liggend), pols $94 / \mathrm{min}$. regulair aequaal, temperatuur $38,6^{\circ} \mathrm{C}$. CVD bdz. $\mathrm{R}-4 \mathrm{~cm} \mathrm{H} \mathrm{H}_{2} \mathrm{O}$, ademfrequentie $22 / \mathrm{min}$.

Pupilreacties gb, volgbewegingen gb, sclerae gb, kloppijn sinus-, mond: geen afwijkingen slijmvlies, geen beslag op tong, keel gb, lymfklieren hals-, schildklier niet palpabel, Aa. carotides: bdz. $+/+$, geen souffles.

Symmetrisch bewegende thorax. Longen: links dorsobasaal demping ongeveer een handbreedte, verder sonore percussie, verschuiving longgrens: links niet aanwijsbaar, rechts twee vingers. Linksonder een gebied met crepitaties en verscherpt ademgeruis, verder vesiculair ademgeruis bdz., expirium normaal. Cor: ictus niet palpabel, S1 en S2 gb, geen extra tonen / souffles.

Geen afwijkingen. 


\section{Vervolg figuur 2.}

Rug/wervelkolom:

Extremiteiten:

Rectaal Toucher/

Vaginaal Toucher:
Geen afwijkingen.

Reflexen: KPR en VZR en APR symmetrisch. Pulsaties intact.

\section{Lijst met activerende gegevens}
1. 1 week griep
8. Incontinentie bij drukverhoging
2. Moe
9. Rugpijn
3. Benauwdheid
10. Verhoogde ademfrequentie
4. Hoesten met opgeven sputum
11. Demping en crepitaties links
5. Gewichtsafname dorsobasaal over de long
6. Nachtzweten
12. Koorts $38.6^{\circ} \mathrm{C}$
7. Oedeem enkels

\section{Probleemlijst (bijbehorende activerende gegevens)}
1. Dyspnoe $(3,10)$
5. Nachtzweten (6)
2. Productieve hoest en koorts $(1,4,11,12)$
6. Oedeem enkels (7)
3. Moe (2)
7. Incontinentie (8)
4. Gewichtsafname (5)
8. Rugpijn (9)

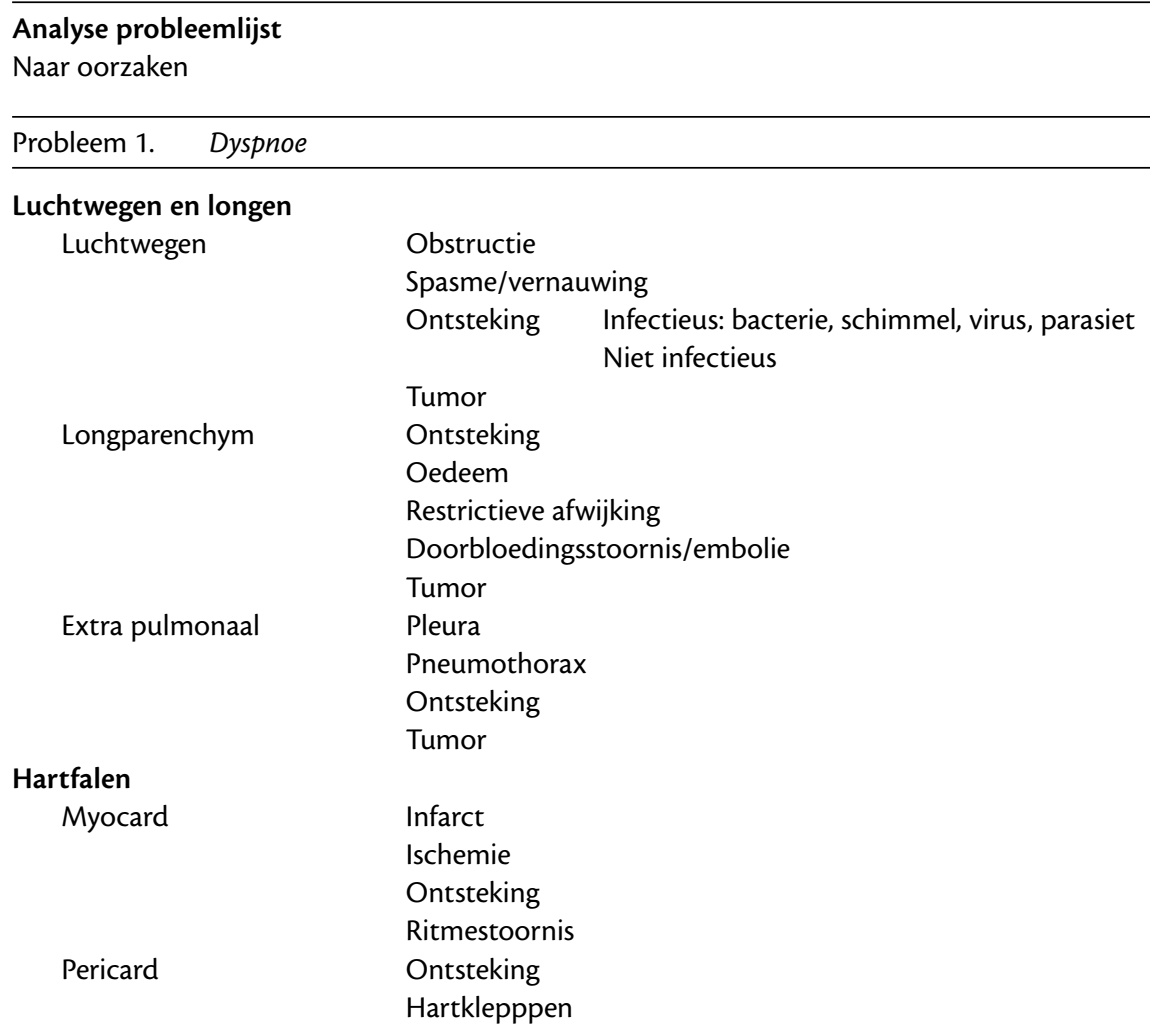


Vervolg figuur 2.

\author{
Belemmering ademexcursie \\ Thoraxwand \\ Abdomen \\ Diafragma \\ Stoornis in zuurstoftransport \\ Anemie \\ Intoxicatie \\ Overig \\ Psychische/neurologische oorzaken
}

\author{
Probleem 2. Productieve hoest en koorts \\ Lage luchtweginfectie \\ Bacterieel pneumococ, staphylococ \\ Viraal \\ Schimmel \\ Parasitair \\ Longembolie / Secundair geïnfecteerd
}

Probleem 3. Moeheid

\author{
Secundair aan probleem 1 en 2 \\ Andere oorzaken \\ Toxisch/medicamenteus \\ Allergisch/immunologisch \\ Idiopathisch \\ Neoplasmata \\ Endocriene ziekten \\ Ernstige en/of chronische orgaanaandoeningen
}

De overige problemen worden op overeenkomstige wijze geanalyseerd. Indien er op grond van aanvullende gegevens, waaronder zogenaamde negatieve bevindingen, gerede verdenking in de richting van een van de uitkomsten van de analyse bestaat, wordt de analyse op dit punt verder uitgewerkt. In dit voorbeeld is de verdenking op een pneumonie reëel. De analyse van probleem 1 en 2 wordt dan op het punt van de verwekker bij de infectie als oorzaak verder uitgewerkt.

De Klinische Probleemanalyse in de praktisch klinische blokken

De blokken PKO-1 en -2 zijn kleinschalig van opzet. In deze blokken worden groepen van negen tot twaalf studenten door één tutor begeleid. Het blok PKO-1 duurt vier weken en vindt plaats in het begin van het derde studiejaar. PKO-2 gaat direct vooraf aan het eerste klinische co-assistentschap in het vijfde jaar en duurt eveneens vier weken. In deze blokken benadert de voor de Klinische Probleemanalyse gebruikte casuïstiek de realiteit het dichtst. In vier bijeenkomsten van ieder drie uur contacttijd staan de probleemoplossingsvaardigheden centraal. In de eerste sessie krijgen alle studenten een (schriftelijk) uitgewerkte ziektegeschiedenis uitgereikt. De casuïstiek is afkomstig van klinische en poliklinische 
patiënten van de afdeling interne geneeskunde. Het gaat om realistische casus, die gestructureerd en op een uniforme wijze aangeboden worden. In vergelijking met de casus waarmee men in voorgaande blokken heeft kennisgemaakt, ligt de moeilijkheidsgraad een niveau hoger onder meer omdat alle elementen uit de ziektegeschiedenissen zijn opgenomen. In groepjes van drie formuleren de studenten de activerende gegevens, de probleemlijst en een analyse per probleem of differentiaaldiagnose. Zo nodig worden leerboeken geraadpleegd. Onder begeleiding van de tutor worden de resultaten vervolgens 'plenair' in de groep van negen tot twaalf studenten gerapporteerd en beargumenteerd. Op deze wijze leert men van elkaar, de tutor heeft uitdrukkelijk een begeleidende taak. ${ }^{11} 1314$ Een van de groepjes heeft bovendien een modelstatus van de betreffende patiënt waarin laboratoriumuitslagen en gegevens van aanvullend onderzoek (röntgenfoto's, uitslagen van pathologie, scopieverslagen) zijn opgenomen, evenals bijvoorbeeld consultaanvragen met het bijbehorende antwoord. De studenten selecteren hieruit de naar hun mening relevante gegevens en sturen een tweede cyclus van de probleemanalyse aan door deze informatie aan de rest van de groep te presenteren.

In de tweede sessie wordt de realiteit dichter benaderd door te starten met een video-opname van een anamnese van een patiënt op de polikliniek interne geneeskunde. Tijdens het bekijken van de band noteren de studenten wat zij als de activerende gegevens beschouwen. Hierna ontvangen zij het verslag van het lichamelijk onderzoek zodat ze een volledige probleemlijst van deze patiënt kunnen maken. Ook zijn alle aanvullende gegevens weer beschikbaar in een modelstatus. Tijdens het vervolg van het blok PKO-2 oefenen de studenten het afnemen van de anamnese, het analyseren van de gegevens volgens de geschetste methodiek en verslaglegging in contacten met simulatiepatiënten, met patiënten in een huisartsenpraktijk, bij een patiënt thuis en tijdens de bedside-teachings op de $\mathrm{k}$ linische afdelingen.

\section{De docenten}

Sinds de start van het nieuwe curriculum zijn er in het derde jaar 18 en in het vierde jaar 32 tutoren die in de blokken PKO vrijwel al het klinisch vaardigheidsonderwijs verzorgen. De tutoren zijn allen praktisch werkzame specialisten van de kliniek interne geneeskunde of van de afdeling huisartsgeneeskunde. Gemiddeld begeleiden zij eens per jaar gedurende vier weken een groep van negen tot twaalf studenten. Deze tutoren begeleiden ook het bovengeschetste proces van de Klinische Probleemanalyse. Zij zijn hierop voorbereid middels docententrainingen. Inmiddels is het model van de Klinische Probleemanalyse zover doorgevoerd dat het voor veel clinici die ook als tutor werken gemeengoed is geworden. Verder is er voor iedere casus uitgewerkt docentenmateriaal met toelichting. Naast deze specifieke taak voor de tutoren in het PKO wordt er ook in de andere blokken aandacht besteed aan de Klinische Probleemanalyse onder begeleiding van de docenten van de betreffende blokken.

\section{Ervaringen in de praktijk}

\section{Van oud naar nieuw curriculum}

Aanvankelijk werd de systematiek van de Klinische Probleemanalyse alleen toegepast bij de besprekingen in het co-assistentschap interne geneeskunde waarbij de co-assistenten patiënten voordroegen. Hierdoor raakten de studenten pas vrij laat in hun studie bekend en vertrouwd met de Klinische Probleemanalyse. Bij de 
begeleiders van de besprekingen rees de verwachting dat deze analyses en presentaties zouden verbeteren als de co-assistenten vanaf het begin van hun studie vertrouwd zouden zijn met de systematiek.

Met de start van het nieuwe curriculum in 1995 werd de Klinische Probleemanalyse ook in de kernblokken ingevoerd. Gaandeweg werd de bovengeschetste situering van de Klinische Probleemanalyse in het curriculum gerealiseerd. Bij de constructie van de blokken werd expliciet aandacht besteed aan de Klinische Probleemanalyse binnen het onderwijsprogramma. Ook bij de vernieuwing van de programma's van de co-assistentschappen vond dit plaats. Zowel in het academisch ziekenhuis als in de geaffilieerde klinieken worden de patiëntenvoordrachten van de co-assistenten, sinds de invoering van de vernieuwde co-assistentschappen in 2000, volgens de aanpak van de Klinische Probleemanalyse uitgevoerd.

De invoering van de methodiek vereiste een continue scholing en uitleg aan alle betrokken docenten. Ter ondersteuning werden vanuit de initiatiefgroep studiemateriaal en docenteninstructie ontwikkeld. Het bijsturen van het proces vereist vrijwel voortdurend aandacht omdat de tendens bestond en bestaat om individuele aanpassingen in te voeren waardoor er steeds grotere afwijkingen van de oorspronkelijke opzet zouden kunnen ontstaan. Een belangrijk kenmerk van dit probleemoplossen is dat het een dynamisch proces is waarvoor geen receptenboek kan worden aangereikt. Het geeft steeds aanleiding tot discussie, met name over het benoemen van de problemen en het onderbrengen van de activerende gegevens.

De kwaliteit van het onderwijsmateriaal wordt bewaakt, vanuit zowel medisch-inhoudelijk als onderwijskundig oogpunt. Er wordt op toegezien dat de diversiteit van de uitgewerkte casuïstiek voldoende is. Het realiteitsgehalte van de onderwijsmaterialen wordt verhoogd door gebruik te maken van video-opnamen van anamnesegesprekken en de aanvullende gegevens te verschaffen in de vorm van röntgenfoto's en dergelijke en niet alleen als schriftelijke beschrijvingen.

Tot en met het laatste studiejaar wordt de geschetste methode aangeboden. De ervaring leert dat tijdens de co-assistentschappen het methodisch probleemoplossen zodanig in het dagelijkse handelen van de co-assistenten is geïncorporeerd dat deze voor de dagelijkse gang van zaken vanzelfsprekend is geworden.

\section{Wat vinden studenten en docenten?}

Van de eerste 100 studenten zijn de gegevens verzameld in het kader van de continue onderwijsevaluatie van het U.M.C. St. Radboud. Voor het onderdeel Klinische Probleemanalyse tijdens PKO-2 werd er gevraagd naar een waardering van inhoud, vorm en begeleiding. Op een vijfpuntsschaal (1=zeer slecht; 5 =zeer goed) werd de inhoud beoordeeld met 4.3 (sd. 0.8), de vorm met 3.9 (sd. 0.8) en de begeleiding met 4.0 (sd. 0.7). Hiermee is het een van de meest gewaardeerde onderdelen van het blok PKO-2. Ook de tutoren waarderen de verdere ontwikkeling van het concept en de incorporatie in de onderwijsprogramma's.

\section{Beschouwing}

De beschreven structuur en methodiek van de Klinische Probleemanalyse geeft docenten de mogelijkheid het onderwijs in het probleemoplossen op heldere en systematische wijze over te dragen. Het gebruik van casuïstische gegevens die geleidelijk ingewikkelder, maar ook realistischer worden, motiveert de stude ten tot een actief leerproces. In uitvoering en context wordt de praktijk steeds dichter benaderd. 
De rol van de docent bij dit onderwijs verandert van kennisoverdrager in die van begeleider van het redeneerproces. Deze afname van de ondersteuning door de docent ('scaffolding') heeft een positieve invloed op het leren van studenten.

Tijdens de besprekingen, zowel in groepjes van drie, als plenair in de groepen van negen tot twaalf studenten, wordt een activatie bewerkstelligd van reeds aanwezige kennis, die daardoor beter en sneller aangewend, gecorrigeerd en/of aangevuld kan worden.

Meer onderzoek naar de kennisverwerving en -benutting bij medisch probleemoplossen is in het licht van het klinisch onderwijs zeker gewenst. Het betreft immers een essentieel onderdeel van de medische competentie. Veel is reeds bekend maar het onderwijs zal beter ontworpen kunnen worden als er meer inzicht is in hoe probleemoplossingsvaardigheden zich in de loop van de tijd ontwikkelen. In onderzoek van Schmidt et al. uit 1994 werden de diagnostische vaardigheden onderzocht bij een steekproef van tweede-, derde-, vierde-, vijfdeen zesdejaars studenten van drie medische faculteiten. ${ }^{15}$ De analyse richtte zich vooral op de relatie van het curriculumtype (probleemgestuurd, geïntegreerd qua basisvakken en klinische vakken - of conventioneel) met diagnostische vaardigheden. Hieruit kwam naar voren dat in het probleemgestuurde en het geïntegreerde curriculum diagnostische vaardigheden zich beter ontwikkelden dan in het conventionele curriculum. Met name vroegtijdig contact met patiënten bleek hierin een belangrijke factor. $\mathrm{Nu}$ er in den lande diverse curriculumwijzigingen geïmplementeerd zijn, zou het interessant zijn om een vergelijkend onderzoek uit te voeren bij meer faculteiten. Niet de relatie tussen diagnostische vaardigheden en curriculumtype zou centraal moeten staan in dit onderzoek, maar de relatie tussen diagnostische vaardigheden en de aanpak van het onderwijs in medisch probleemoplossen.

\section{Literatuur}

1. Boekaerts M, Simons PRJ. Leren en Instructie. Psychologie van de leerling en het leerproces. Assen: Van Gorcum; 1995. p. 48-49.

2. Boshuizen HPA, Schmidt HG. De ontwikkeling van medische expertise; implicaties voor het praktisch en theoretisch medisch onderwijs. In: Metz JCM, Scherpbier AJJA, Vleuten CPM van der, redactie. Medisch Onderwijs in de Praktijk. Assen: Van Gorcum; 1995. p. 25-39.

3. Cate ThJ ten. Kleinschalig theoretisch klinisch lijnonderwijs. Ned Tijdschr Geneeskd 1994;138:123843.

4. Minnen B van, Rossum HJM van. Klinisch redeneren met grote groepen, kan dat. In: Smal JA, Cate ThJ ten, Denekens J, Dikkers JH, Remmen R, Spaai GWG et al. Gezond Onderwijs-6. Houten/Diegem: Bohn Stafleu Van Loghum; 1997. p. 180-184.

5. Huinink S, Sagasser MH, Bastiaans JF, Ittersum FJ van, Gercama AJ, Haan M de. Zeven jaar klinisch lijnonderwijs aan de Vrije Universiteit: het onderwijsmateriaal. In: Spaai GWG, Verweij AMJJ, Remmen R, Dolmans DHJM, Denekens JPM, Smal JA, Albersnagel EPL, Dikkers JH, redactie. Gezond onderwijs-8. Houten/Diegem: Bohn Stafleu Van Loghum; 1999. p. 180-182.

6. Quaak, MJ, Haalboom, JRE, Rutten, GEHM. Ervaringen met Amsterdams kleinschalig klinisch lijnonderwijs in Utrecht. In: Spaaij GWG, Verweij AMJJ, Remmen R, Dolmans DHJM, Denekens JPM, Smal JA, Albersnagel EPL, Dikkers JH, redactie. Gezond onderwijs-8. Houten/Diegem: Bohn Stafleu Van Loghum; 1999. p. 244-245.

7. Jongh $\mathrm{TOH}$ de, Ruijven AGH van. Oefening in diagnostische besluitvorming voor co-assistenten. In: Verweij AMJJ, Albersnagel EA, Cate ThJ ten, Denekens J, Dikkers JH, Remmen R, Smal JA, Spaaij GWG, redactie. Gezond onderwijs-7. Houten/Diegem: Bohn Stafleu Van Loghum; 1998. p. 161-162.

8. Wiel MWJ van de, Schaper NC, Scherpbier AJJA, Vleuten CPM van der, Boshuizen HPA. Focusgroeponderzoek naar de ervaringen van studenten in onderwijsgroepen met echte patiënten. In: Verweij AMJJ, Albersnagel EA, Cate ThJ ten, Denekens J, Dikkers JH, Remmen R, Smal JA, Spaaij GWG, redactie. Gezond onderwijs-7. Houten/Diegem: Bohn Stafleu Van Loghum; 1998. p. 325-327.

9. Gercama AJ. Medisch-probleemoplossen in kleine groepen; proberen om van te leren. In: 
Verweij AMJJ, Albersnagel EA, Cate ThJ ten, Denekens J, Dikkers JH, Remmen R, Smal JA, Spaaij GWG, redactie. Gezond onderwijs-7. Houten/Diegem: Bohn Stafleu Van Loghum; 1998. p. 111-113.

10. Rutten GEHM, Borleffs JCC, Cate ThJ ten. Onderdelen van CRU'99. Klinisch lijnonderwijs. Tijdschrift voor Medisch Onderwijs 2001;21(supplement):S30-S31.

11. Harden RM, Crosby J. The good teacher is more than a lecturer - the twelve roles of the teacher. AMEE Guide No. 20. Med Teach 2000;22:334-47.

12. Custers EJFM, Stuyt PMJ, Vries Robbé PF de. Clinical Problem Analysis (CPA). A systematic approach to teaching complex medical problem solving. Acad Med 2000;75:291-7.

13. Boekaerts M, Simons PRJ. Leren en Instructie. Psychologie van de leerling en het leerproces. Assen: Van Gorcum; 1995. p. 165-167.

14. Boekaerts M, Simons PRJ. Leren en Instructie. Psychologie van de leerling en het leerproces. Assen: Van Gorcum; 1995. p. 241-256.

15. Schmidt HG, Machiels-Bongaerts M, Hermans H, Cate ThJ ten, Venekamp R, Boshuizen HPA. The development of diagnostic competence: comparison of a problem-based, an integrated, and a conventional medical curriculum. Acad Med 1996;76:658-64.
16. Vries Robbé PF de, Stuyt PMJ, Meer JWM van der. Onderwijs in methodisch denken in de praktische geneeskunde. In: Metz JCM, Scherpbier AJJA, Vleuten CPM van der, redactie. Medisch Onderwijs in de Praktijk. Assen: Van Gorcum; 1995. p. 58-68.

17. Norman GR, Schmidt HG. Effectiveness of problem-based learning curricula. Med Educ 2000;34:721-8.

\section{De auteurs:}

Mw. J.C.G. Jacobs, arts-onderwijskundige, Klinisch Trainingscentrum.

Mw. B.M. Cools, internist, waarnemend blokcoördinator Praktisch Klinisch Onderwijs-2, Algemeen Interne Geneeskunde.

Dr. C.T. Postma, internist, blokcoördinator Praktisch Klinisch Onderwijs-2, Algemeen Interne Geneeskunde. Allen zijn verbonden aan het UMC St. Radboud Nijmegen.

\section{Correspondentieadres:}

Mw. J.C.G. Jacobs, arts-onderwijskundige, Klinisch Trainingscentrum, UMC St. Radboud Nijmegen, (interne postcode 224 KTC), Postbus 9101, 6500 HB Nijmegen, tel.: 024-3616330, fax: 024-3560433, A.Jacobs@osz.kun.nl.

\section{Summary}

Introduction: Since 1995 the students of University Medical Center Nijmegen have been offered a systematic method for analysing medical problems, Clinical Problem Analysis (C.P.A.). This approach helps students to learn to relate basic science concepts to patient histories. Especially during the modules in the core curriculum the use of C.P.A. in the analysis of patient cases related to the content of the modules contributes to the learning of students.

Description: Different methods of teaching clinical reasoning and medical problem solving are briefly presented. C.P.A. as used in the Nijmegen curriculum is described. The way C.P.A. is implemented in the Practical Clinical Courses in years 3 and 4 is described in detail. In these courses the patient cases are highly realistic ones, adapted from actual patient cases from the Department of Internal Medicine. In a realistic manner uniform 'model-cases' were constructed that contain a diversity of information for the students. The cases are supplemented by patient charts, additional information and videotaped patient histories. Students continue to use C.P.A. during the clinical and central clerkships. Both teachers and students are appreciative of this approach.

Discussion: C.P.A. offers a structured approach to medical problem solving that can be used throughout the undergraduate curriculum with increasingly realistic case histories. Students are stimulated to activate their previous knowledge and to actively participate in the learning process. A comparative study of the outcomes of the different approaches to medical problem solving used in Dutch medical schools is proposed. (Jacobs JCG, Cools BM, Postma CT. Clinical Problem Analysis: an approach to teaching medical problem solving in the Nijmegen undergraduate medical curriculum. Dutch Journal of Medical Education 2002;21(2):64-74.) 